\title{
SOCIAL BENEFITS AGAINST POVERTY OF SINGLE PARENT FOR SOCIAL INVESTMENT ${ }^{1}$
}

\author{
Daiva Skuciene \\ $\mathrm{PhD}$
}

\begin{abstract}
Compensatory welfare is less sensible for "new" social risks including single parenthood nowadays. Thus, social investment policy seeks to combine work and family responsibilities for single parents to enable them to avoid poverty. On the other hand, social investment can be perceived as the other pillar together with compensatory social protection, which is important for single parent families as a tool protecting against poverty. Among the three welfare sources, i.e. family, market and state, the state should support the single parents (Christopher, 2002; Nieuwenhuis and Maldonado (2016)). The aim of this research is to analyse the impact of social benefits on the poverty reduction of single parents in the Baltic States with a focus on social investment. The following objectives are set up for the implementation of the aim: to review discourse about social investment, its relation with traditional social protection and life course perspective; to analyse the income and the poverty, as well as to analyse the impact of social benefits on poverty reduction. The empirical data of the research are obtained from the EU-SILC microdata of the period of 2007-2015 aiming to evaluate the prevailing trend. The analysis of the impact of social benefits on poverty reduction was made using a sequential approach, when the impact on poverty reduction of each type of social benefit is measured separately step by step. The impact of social benefits on poverty reduction among single parents was evaluated over the life course because social investment is a life course policy. The findings of the research revealed that social benefits have quite a small impact on poverty reduction in single parent families. The poverty after social benefits among single parents remains high and stable during 2007-2015. Additionally, the poverty of single parents in Baltic States is feminized.
\end{abstract}

Keywords: single parents, social benefits, social investment, life course, Baltic States, income, poverty

\section{Introduction}

A relatively high rate of divorce is typical of the Baltic States: during the period of 2014-2015 more than 40\% families got divorced in Lithuania.

1 The author would like to thank Ausra Cizauskaite for the assistance with technical calculations of the data during research project.

The research was funded by a grant (No. Ger-009/2017) from the Research Council of Lithuania 
This indicator equalled about $50 \%$ in Estonia and $50-58 \%$ in Latvia. Thus, households of single parents have become a reality of society life. Households of single parents are perceived as a "new" social risk due to a wider spread of poverty and need for employment combining it with children's care (Esping-Andersen, 2002; Bonoli 2006). However, compensatory social policy (social insurance) has become less sensitive to new social risks (Esping-Andersen, 2002, Hemerijck, 2013). Social investment policy, as supplementing compensatory welfare, could contribute to reduction of poverty among single parents creating favourable conditions for their employment. Despite that, the compensatory welfare remains important and social investment is not a substitute for it. Compensatory welfare and social investment are rather two pillars of welfare (Hemerijck, 2013).

The aim of this research and contribution of this research is to add the knowledge about the impact of social benefits on the poverty reduction of single parents in the Baltic States with a focus on social investment.

The article consists of the following parts: the review of discourse about social investment, its relation with the traditional social protection and life course perspective. It also presents the analysis of the income and the poverty, as well as the analysis of impact of social benefits on the poverty reduction. The empirical data of the article are obtained from the EU-SILC microdata of the period of 2007-2015. The impact of social benefits on poverty reduction among single parents was evaluated over the life course, because social investment is a life course policy. The analysis of the impact of social benefits on poverty reduction was made using the sequential approach, when the impact on poverty reduction of each type of social benefit was measured separately step by step. The calculation was made during the research project "Income smoothing over the life course from social investment perspective in the Baltic States" in 2018. An attempt was made to compare the data of 2007 and 2015 in order to identify the prevailing trend in data.

\section{Social investment and compensatory welfare over the life course}

The social investment paradigm focuses on enhancement of human capital in order to ensure participation in the labour market (EspingAndersen, 2002; Bonoli, 2006; 2013; Hemerijck, 2017). According to Cooke and Gazso (2009), the main idea of social investment is the shift from passive social protection to active welfare programmes. Activation refers to any policy that enhances the capabilities of citizens, as proposed by Esping-Andersen (2002). Esping-Andersen (2002) contends that activation encourages one to seek a job more actively, and activation begins in early childhood. Thus, early childhood learning is of primary importance (see Jenson and Saint-Martin, 2005; Jenson, 2010; Bonoli, 2013; 
Hemerijck, 2017). Hemerijck (2017) defines social investment as serving the "stock", "flow" and "buffer" functions. The "stock" function of social investment strengthens people's skills and capacities. The "flow" function helps to bridge critical life course transitions from schooling to the first job, etc., while income protection serves as a "buffer" function of social investment; the "buffer" helps to compensate and mitigate social inequity at the micro level and provides the necessary financial security for people to develop their human capital.

The same ideas were expressed by Nolan (2013), Pintelon et al. (2013), Kvist (2014) and Kuitto (2016). According to them, although recently there has been a lot of focus on the development of human capital over the life course, analysis of social investment should include welfare programmes which ensure consumption. Following the words of Esping-Andersen (2002), adequate income maintenance is the first precondition for preventive or remedial strategies. And according to Nolan (2013), investment cannot be understood without current consumption because investment primarily relates to the health of the future labour force. Farrington and Slater (2006) state that cash transfers have not only a consumption effect, but also an effect on the demand for food, investment in health and education. Indeed, social investment as a new welfare policy should combine greater labour market participation and adequate social protection (Pintelon et al., 2013). Kuitto (2016) notes that compensation and social investment policies should be complementary because social protection benefits increase household income, which results in investments in nutrition, health and education. Thus, social protection benefits, in this way, contribute positively to human capital investment and to development, as stated by Midgley (2018, ed. Deeming and Smyth, 2018). Kozek and Kubisa (2016) claim that welfare institutions only need to mitigate deficits in certain stages of the lives of individuals and families (ed. Halvorsen and Hvidnden, 2016). Therefore, according to Fitzpatrick (2004), institutional supports offer bridges through sensitive periods.

\section{Single parenthood as a new social risk}

Single parenthood was called a "new" social risk group, where poverty rate is high (Bonoli, 2006; Busemeyer and Neimanns, 2017). Following Bonoli (2007), it relates to socioeconomic transformations, which shifted the target of social policies away from the male breadwinner and towards women and younger, often low-skilled people. Therefore, the reconciliation of work and family life would be the solution avoiding the poverty for single parents. For that aim it is necessary to combine subsidised day care with income guarantees as emphasised by Esping-Andersen (2002). According to Esping-Andersen (2002), lone mothers will usually need 
additional income support in order to escape poverty. The findings of Nieuwenhuis and Maldonado (2016) proved the positive effect of social protection benefits on poverty reduction of single parents. They found that parental leave facilitated employment among single parent families, in turn reducing their poverty. The transfers of family allowances were associated with a substantial reduction in poverty, particularly among single-parent families (Nieuwenhuis and Maldonado (2016).

The importance of social benefits during critical life events is significant for single parent households. In the family, individuals are usually supported by income from a spouse or partner or another family member (Christopher, 2002). In the case of single parenthood this support is not always ensured and a single person lives with children from the income of one person. Thus, among the three welfare sources, i.e. family, market and state, the state should support the single parents (Christopher, 2002; Nieuwenhuis and Maldonado, 2016). Another reason for the poverty among single parents was observed by Nieuwenhuis and Maldonado (2016). They point out that single parenthood is strongly gendered. Single mothers are more likely to face economic disadvantage as compared to single fathers. On average, women have lower earnings than men due to the gender wage gap and occupation segregation by gender, which is stronger among mothers. The majority of women graduate in humanities, which typically have lower earnings potential than graduates from the science (Nieuwenhuis and Maldonado, 2016).

As observed by Nieuwenhuis and Maldonado (2016), the child benefits targeted specifically towards single parents are more effective in reducing their poverty than universal policies for all. Another significant factor to reduce in-work poverty for single parent families is child support.

Nieuwenhuis and Maldonado (2016) doubted employment being an instrument against poverty, especially if the employment was of low quality: jobs with inadequate wages, of a temporary nature, high instability and with few opportunities for promotion. This concern has been raised particularly for those already in weaker socio-economic positions, such as single parents.

\section{Data and methods}

EU-SILC microdata of the period of 2007-2015 were used for the implementation of the set aim and objectives. Single parents were selected on the basis of household. The impact of social benefits on poverty reduction among single parents was evaluated over the life course because social investment is a life course policy. For the evaluation of the impact of social benefits on poverty reduction the sequential approach was used. Firstly, at-risk-of-poverty rate and gap were calculated for income from 
the market and after that each social benefit was added to the income package and again at-risk-of-poverty rate was calculated and compared with the previous one.

For the calculation of at-risk-of-poverty and poverty gap the standard measurements were applied. The OECD equivalence scale was also used.

The income of single parents was compared with the income of couples with children and the average income of the country. The data of Eurostat were used for the analysis of poverty rate of groups of social benefit receivers.

\section{Social benefits against poverty for single parenthood in Baltic States}

Single parenthood in the Baltic States, as observed by Nieuwenhuis and Maldonado (2018) in their research, is strongly feminised. 73.5\% of single parents were women in Lithuania and $77.9 \%$ in Latvia, $77.4 \%$ in Estonia in 2015.

\section{Income and poverty}

The income situation of single parents is characterised comparing it with another close group: income of couples and the average income in the country. Income of single parents was about one third lower compared with that of couples with children in Lithuania and about one fourth lower in Estonia and Latvia. In comparison with the average income in a country the income of single parents was yet lower: more than one third in Lithuania, about one third in Estonia and Latvia in 2015 (see: Table 1). Income of single parents was lower in 2007 in Estonia compared with that in 2015, while in Lithuania and Latvia the income of single parents in 2007 was higher compared with that in 2015.

Table 1. Average income of single parents compared with income of other groups in $2007-2015, \%$

\begin{tabular}{|c|c|c|c|c|}
\hline State & \multicolumn{2}{|c|}{ With income of couples with children } & \multicolumn{2}{c|}{ With the average income in the country } \\
\hline & $\mathbf{2 0 0 7}$ & $\mathbf{2 0 1 5}$ & $\mathbf{2 0 0 7}$ & $\mathbf{2 0 1 5}$ \\
\hline LT & 78.11 & 70.60 & 74.60 & 67.48 \\
\hline LV & 81.05 & 76.42 & 81.47 & 73.66 \\
\hline EE & 66.63 & 74.92 & 66.24 & 70.49 \\
\hline
\end{tabular}

Source: Author's calculations 
The low income of single parents is related to a high poverty rate of such groups. Looking at the life course, high poverty rates after retirement can also be observed (see: Figure 1).

The at-risk-of-poverty rate was one third higher in the group of youngest people (18-24 years old) in Lithuania and Estonia and it was about one fourth higher in Latvia in 2015. Comparing the poverty rate in 2015 with the data of 2007 in the age group of 18-24 years, a decrease in the poverty rate in Estonia can be observed. However, this indicator increased in Lithuania.

The poverty rate during the working career and the period of children growing (25-45 years old) is extremely high: about half in Lithuania and Estonia (25-35 years old), more than one third in Latvia in 2015. A similar trend was identified in 2007 as well. Despite that, the at-risk-of-poverty rate among single parents in the age group of 25-35 years increased in 2015 in all the three Baltic States compared with 2007. The at-risk-ofpoverty rate in the group of single parents aged 36-45 years increased in Lithuania and Latvia in 2015 compared with the same age group of single parents in 2007, whereas this indicator was lower in Estonia (see: Figure 1).

Slightly less than one third of single parents lived in poverty in Latvia and Estonia (36-45 years old) and about half in Lithuania in 2015. For the oldest group of single parents, the at-risk-of-poverty rate decreased in 2015 compared with 2007.

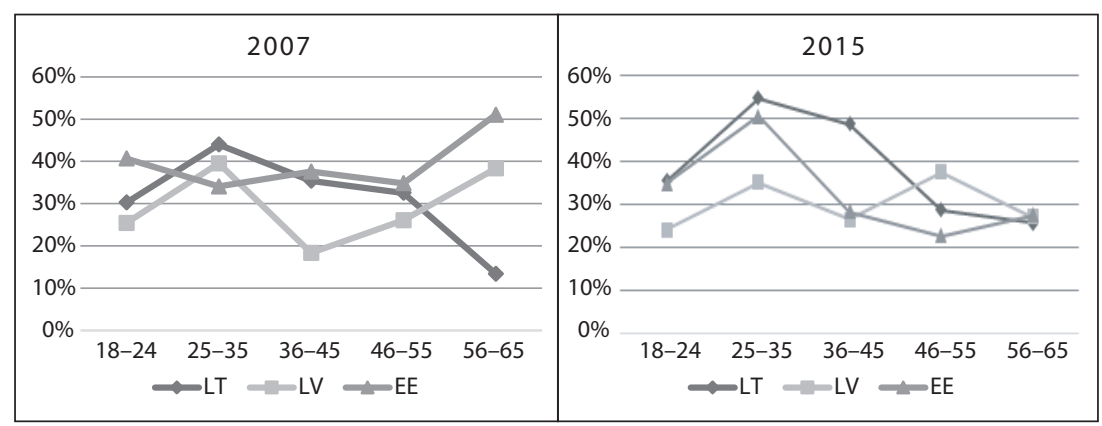

Source: Author's calculations

Figure 1. The at-risk-of-poverty rate of single parents over the life course, 2007-2015

The lower income in the Baltic States and persistently high poverty during eight years among single parents is not an adequate "buffer" for children growing in such households. The importance of adequate income 
for human capital development as a "buffer" was emphasised by EspingAndersen (2002) and Hemerijck (2017). Yet more insufficient income and poverty over the life course transfers into the poverty after retirement, as the social insurance retirement schemes depend on the previous earnings. This is predetermined by the fact that the social insurance old age pension is the main income source in the income package of retirees in the Baltic States.

As single parenthood is a particular type of household, which certainly not always, but rather frequently lacks financial support from the spouse in the family. So, welfare state benefits and income from the labour market have to be adequate in order to avoid the poverty within this group. As stated by Esping-Andersen (2002) the following welfare benefits, such as family cash benefits, maintenance advances and social assistance are ineffective tools in the case of lone mothers. This finding was tested in the Baltic States using separate types of social benefits, including old age pensions.

Generally, the social benefits reduced the at-risk-of-poverty rate of single parents about 10 percent points in all the Baltic States in 2007-2015. However, it remained high after the social transfers in all the Baltic States in 2007-2015 (see: Table 2). The poverty rate after social benefits was lower only in Estonia in 2015 compared with 2007, whereas it increased in Latvia and Lithuania.

Analysing the impact of separate types of social benefits on the poverty reduction, it can be stated that child/family and survivor/orphan benefits had the relatively highest impact. The impact of child benefit on poverty reduction decreased in 2015 in Lithuania and Estonia compared with 2007. The impact of unemployment and social exclusion benefits on poverty reduction was insignificant in all the Baltic States in the period of 20072015 (see: Table 2).

To sum up, the present research confirms the finding of Esping- Andersen (2002), who stated that a child benefit is insufficient for the abolishment of poverty in families. The tax concessions and other complementary social policy means combined with employment could help single parents to avoid poverty. On other hand, the employment should ensure adequate pay jobs for single parents, because low paid jobs do not solve the problem of poverty. About $10 \%$ of single parents in LT and $7 \%$ - in LV and $9 \%$ - in EE were unemployed in 2015. About $30 \%$ of single parents in all the Baltic States were low skilled (0-2 ISCED level) in 2015. It can be related to the data of in-work poverty of single parents. In-work poverty of single parent equalled $25.2 \%$ in EE; $26.3 \%$ - in LV and $32.1 \%$ - in LT.

Therefore, these data allow stating that the support of welfare state is the most important source for single parents in the Baltic States. 
The overlap of single parenthood with low education is another risk for reduced income from the market (insecure, low pay work). On other hand, the contextual particularities of the Baltic States, where wages are low, increase the importance of welfare state benefits. If in Western countries the main concern is how to combine child care and work (Nieuwenhuis and Maldonado (2018), in the Baltic States additional issue how to ensure sustainable and adequate paid employment is observed.

Table 2. Single parents at risk of poverty after types of social benefits in the Baltic States in 2007-2015

\begin{tabular}{|l|r|r|r|r|r|r|}
\hline & \multicolumn{3}{|c|}{2007} & \multicolumn{3}{c|}{2015} \\
\cline { 2 - 7 } & LT & \multicolumn{1}{c|}{ LV } & \multicolumn{1}{c|}{ EE } & \multicolumn{1}{c|}{ LT } & \multicolumn{1}{c|}{ LV } & EE \\
\hline Poverty rate before social benefits, \% & 46.9 & 38.2 & 49.3 & 50.7 & 43.0 & 44.2 \\
\hline Reduction of poverty rate by social benefits: & -1.7 & -1.0 & -0.2 & -0.5 & -0.4 & -0.9 \\
\hline Old age pension & -0.2 & -1.1 & 0.0 & -0.4 & 0.0 & -1.0 \\
\hline Unemployment benefits & -2.5 & -2.2 & -2.2 & -4.8 & -1.7 & -0.4 \\
\hline Survivor / orphan benefits & -0.5 & -0.5 & 0.0 & -0.4 & -1.4 & -0.1 \\
\hline Sickness benefits & -1.6 & -0.4 & -1.3 & -0.3 & -2.3 & -3.2 \\
\hline Disability benefits & -4.2 & -4.1 & -4.9 & -1.5 & -6.4 & -3.1 \\
\hline Child/family benefits & 0.0 & -1.4 & 0.0 & -0.5 & -0.5 & 0.0 \\
\hline Soc. exclusion benefits & 36.1 & 27.4 & 40.7 & 42.3 & 30.3 & 35.5 \\
\hline Poverty rate after social benefits, \% & -10.7 & -10.8 & -8.6 & -8.4 & -12.7 & -8.7 \\
\hline The scope of poverty reduction, \% & & & & & & \\
\hline
\end{tabular}

Source: Author's calculations

The analysis of the poverty gap before social benefits of single parents in the Baltic States shows that income of that group is more than $50 \%$ lower than the poverty line. In all the three Baltic States disability and child/family benefits had a relatively significant impact on the poverty gap. This can be related to the size of such benefits: for example, a disability benefit is usually calculated as old age pension and its amount depends on the level of incapacity, whereas the child/family benefits include parental leave benefit, which is quite generous in the Baltic States. In the period of 2007-2015 social exclusion benefits had a relatively considerable influence on the poverty gap in Lithuania as well as old age pension because a part of the persons in the group 56-65 year were retirees. Old age pension is one of the most generous social benefits compared with others. A rather low impact of social benefits on the reduction of poverty gap in the Baltic States is related to low generosity of benefits. The funding of social security expenditure was lower in the Baltic States almost twice the EU average in 2015 (source: Eurostat). 
Table 3. Poverty gap of single parents after types of social benefits in Baltic States in 2015

\begin{tabular}{|l|r|r|r|r|r|r|}
\hline & \multicolumn{7}{|c|}{2007} & \multicolumn{3}{c|}{2015} \\
\cline { 2 - 8 } & LT & LV & EE & LT & LV & EE \\
\hline Poverty gap before social benefits, \% & 57 & 55 & 55 & 59 & 52 & 53 \\
\hline Reduction of poverty gap by social benefits: & -5 & -4 & -7 & 0 & -4 & -2 \\
\hline Old age pension & -1 & 0 & 0 & -2 & -2 & -1 \\
\hline Unemployment benefits & -1 & -2 & -1 & 1 & 0 & 0 \\
\hline Survivor / orphan benefits & 0 & 0 & 0 & -1 & 0 & -1 \\
\hline Sickness benefits & -9 & -3 & -6 & -5 & -3 & -7 \\
\hline Disability benefits & -4 & -11 & -7 & -7 & -3 & -6 \\
\hline Child/family benefits & -3 & 1 & 0 & -5 & -1 & 0 \\
\hline Soc. exclusion benefits & 34 & 37 & 34 & 40 & 39 & 36 \\
\hline Poverty gap after social benefits, \% & -23 & -18 & -20 & -20 & -13 & -17 \\
\hline The scope of the reduction of poverty gap, \% & & & & & & \\
\hline
\end{tabular}

Source: Author's calculation

Elaborating on the inefficiency of traditional welfare benefit for abolishment the poverty of single parents, Esping-Andersen (2002) mentioned that other social policy tools, such as direct family cash transfers, can help single parents in poverty. Looking at the family policy tools for single parents in the Baltic States, it can be observed that only Estonia has a supplement to the general child allowance, Lithuania only offers reduced payment in pre-school institutions, whereas no supplements have been identified in Latvia (source MISSOC, 01/01/2015). The right to other benefits is not distinguished for single parent families separately.

\section{Concluding remarks}

Social investment is a policy focusing on a human capital development over the life course. Adequate income maintenance is required for successful social investment.

Single parenthood in the Baltic States can be characterised as a new risk group with a high poverty rate over the life course, especially during the children growth period. As the income formation is based on the following three sources: the market, the family and the welfare state, single parenthood in the Baltic States cannot be adequately supplied from any of those three. Low education overlapping with single parenthood cannot ensure good work and, as a consequence, results in high work poverty among single parents. Moreover, social benefits are focused on a traditional 
family in the Baltic States. Thus, the social benefits have quite a small impact on poverty reduction among single parent families, especially in Lithuania. And family child benefits are insufficient for avoiding poverty in the Baltic States, as stated by Esping-Andersen (2002). Poverty after social benefits among single parents is high and stable in the Baltic States. That means cumulative disadvantages of children growing up in such families in the Baltic States. The social protection for single parents requires revision in all the three states.

\section{REFERENCES}

Armingeon, K. \& Bonoli, G. (2006), The politics of post-industrial welfare states. Adapting post-war social policies to new social risks. Routledge: Taylor \& Francis Group.

Bonoli, G. (2013), The origins of active social policy. Oxford: University Press.

Bonoli, G. (2007), Time Matters Postindustrialization, New Social Risks, and Welfare State Adaptation in Advanced Industrial Democracies. Political Studies 40(5), 495-520.

Busemeyer, M. R. (2017), Conflictive preferences towards social investments and transfers in mature welfare states: The cases of unemployment benefits and childcare provision. Journal of European Social Policy, 27(3), 229-246.

Christopher, D. \& Paul, S. (2018), Reforming global social policy: Social investment for sustainable and inclusive growth. Policy Press.

Christopher, K., England, P., Smeeding, T. M., Phillips, K. R. (2002), The gender gap in poverty in modern nations: single motherhood, the market, and the state. Sociological Perspectives 45(3), 219-242.

Cooke, M. \& Gazso, A. (2009), Taking a Life Course Perspective on Social assistance use in Canada: a different approach. Canadian Journal of Sociology 34(2), 349-372.

Esping-Andersen, G., Gallie, D., Hemerijck, A. \& Myles, J. (2002), Why we need a new welfare state. Oxford: University Press.

Farrington, J. \& Slater, R. (2006), Introduction: Cash Transfers: Panacea for Poverty Reduction or Money Down the Drain? Development Policy Review 24(5), 499-511.

Fitzpatrick, T. (2004), Social Policy and Time. Time \& Society 13(2/3), 197-219.

Hemerijck, A. (2017), The uses of social investment. Oxford: University Press.

Hemerijck, A. (2013), Changing welfare states. Oxford: University Press.

Jenson, J. \& Saint-Martin, D. (2006), Building blocks for a new social architecture: the LEGO paradigm of an active society. [Online] Available at: http://www.cccg. umontreal.ca/pdf/Jenson\%20and\%20Saint-Martin-Policy\%20and\%20Politics\%203.pdf (Accessed on 10 September 2017)

Jenson, J. (2010), Diffusing ideas for after-neoliberalism: the social investment perspective in Europe and Latin America. Global Social Policy 10(1), 59-84.

Kuitto, K. (2016), From social security to social investment? Compensating and social investment welfare policies in a life-course perspective. Journal of European Social Policy 26(5), 442-459. 
Kvist, J.A. (2014), Framework for social investment strategies: Integrating generational, life course and gender perspectives in the EU social investment strategy. [Online] Available at: https://jonkvist.files.wordpress.com/2014/10/kvist-2014-a-frameworkfor-social-investment-strategies-cep.pdf (Accessed on 1 September 2017).

Nieuwenhuis, R. \& Maldonado, L. C. (2016), Prepare versus repair? Combining parental leave and family allowances for social investment against single-parent poverty. [Online] Available at: https://socialsecurity.belgium.be/sites/default/files/btsz-12015-nieuwenhuis-maldonado-nl.pdf (Accessed on 15 June 2019)

Nolan, B. (2013), What use is 'social investment'? Journal of European Social Policy 23 (5), 459-468.

Pintelon, O., Cantillon, B., Van den Bosch, K. \& Whelan, C. T. (2013), The social stratification of social risks: the relevance of class for social investment strategies. Journal of European Social Policy 23 (1), 52-67. 